\title{
Mechanisms of Lexical Expansion in Ejagham Language: A Descriptive Analysis
}

\author{
Magdaline BAKUME NKONGHO \\ University of Maroua \\ Cameroon
}

\begin{abstract}
The promotion of African languages through Mother Tongue Education is considered an important component to achieving UNESCO's 2007 Education For All (EFA) and the Millenium Development Goals (MDG). This comes along with enormous challenges including the acquisition of scientific knowledge and technological know-how in the language the people know best. With the advent of globalization, researchers are faced with the genuine problem of providing scientific and technical vocabulary so that African languages can respond to this challenge which is indispensable in the enterprise of national development. The need to express scientific knowledge introduced via western languages, reveal the inadequacy of African languages to cope with the demands of the contact of cultures and civilization. Confronted with such inadequacies, native speakers are often led to spontaneously seeking ways and means of extending their vocabularies so as to cope with the much demands of cultural revolutions. (Chumbow, 1994). This paper provides a descriptive analysis on mechanisms of lexical expansion in Ejagham, a Bantu language spoken in the South West region of Cameroon. The language possesses adequate morphological, morphophonological and morphosyntactic processes to cope with expression of new ideas. It is hoped the discussions will serve as a guide in facilitating lexical innovation as an enterprise in language development and will contribute to the position that any language can be rapidly developed by applying certain language engineering principles and techniques to enable it assume a greater function in education and national development.
\end{abstract}

Key words: Lexical expansion, donor language, recipient language, indigenous language, innovation

\section{0) Introduction}

Languages usually possess adequate morphological and syntactic processes to cope with the expression of new ideas. In the face of a new culture and new knowledge, the felt inadequacy is often the absence of appropriate lexical items to express the new concepts (Mutaka and Tamanji 1995:231). Each community is living by specific activities (rearing, haunting, fishing, carving, etc.) and thus would develop an impressive array of vocabulary to express in details, concepts and activities associated with their experiences. Thus the lexicon of a language is the result of the communal experience of the linguistic community. But this lexicon may be expanded as new experiences come in the community. That is a sign that the adaptation and expansion of a language lexical load is a dynamic process that has no end. Chumbow (1982) identifies the following tendencies in the enrichment of a stock of vocabulary:

a) Spontaneous creation efforts in every day speech for literary and other purposes (including neologism or new words); b) the spontaneous and gradual development of scientific and special vocabulary as new concepts are introduced to the body of knowledge; c) conscious planned formation or creation of terminology in general The first two spontaneous processes are quite general and very common across languages in their gradual development through time. However, since development is not always gradual, a gap is thus often created, especially with regard to African languages, between new knowledge to be expressed and the available medium of communication. As such a deliberate and conscious effort of lexical expansion becomes necessary to bridge the gap between the existing lexicon, and the rapid social economic and scientific progress (Mutaka and Tamanji, ibid). This paper seeks to highlight the various means employed by Ejagham language to expand its different stock of vocabulary.

Ejagham is one of the Bantu languages spoken in the South West Region of Cameroon ${ }^{1}$. It is classified under zone 800(Breton and Fohtung, 1991) Many terms have been used to refer to the dialects or sub-dialects: Ekwe, Eyafin, Keaka, Obang, Etung, Kwa. However the most widespread term of self reference is "Ejagham". Ejagham speakers are found in Cameroon and part of Nigeria. In this language, there are specific techniques based on the observations of what obtains in the spontaneous process of lexical extension.

\footnotetext{
${ }^{1}$ The Ejagham language has three major varieties: Western Ejagham, Eastern Ejagham and Southern Ejagham. There are over 48000 speakers in Cameroon. (Ethnologuge, 2000.P38). The three dialects may be distinguished on the basis of phonological, morphological and lexical differences. (Watters,1981). This work is based on the Eastern Ejagham sub-dialect, spoken in the Eyumojock sub-division of Cameroon.
}

102 
Essentially, three principal methods for expanding its vocabulary are used: borrowing, resuscitation and the exploitation of internal linguistic resources. In the subsequent sections, I will use a descriptive approach backed by illustrative examples to expatiate on each method. But before that, it is necessary to take a cursory view of the shape of lexical items in the language as this will ease the understanding of the modification process of loan items.

\section{2) The Word Structure of Ejagham}

In terms of lexical categories, nouns and verbs are the only lexical items involved in borrowing in this language. Adjective and adverbs hardly become integrated. That is, they often do not go beyond the morpehemic mixing stage. ${ }^{2}$ It is imperative to note here that low tones are unmarked in this write up.

For monosyllabic, disyllabic and trisyllabic forms, nouns present a simple structure: Prefix+Root. Example (a).

(a) $\varepsilon$ - non

$$
\begin{array}{ll}
\multicolumn{1}{c}{\text { "bed" }} & \\
\text { ć-zóyó } & \text { "air" } \\
\text { ć-káßóyó } & \text { "lizard" }
\end{array}
$$

\begin{tabular}{|c|c|c|c|c|}
\hline b) & $\operatorname{Pr}$ & $\mathrm{Rt}$ & $\mathrm{Fv}$ & \\
\hline & $\varepsilon-$ & lay & $\dot{\varepsilon}$ & "to touch" \\
\hline & $\varepsilon-$ & $\operatorname{so} \beta$ & $\dot{\varepsilon}$ & "to boil" \\
\hline & $\varepsilon-$ & 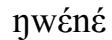 & $\dot{\varepsilon}$ & "to smell" \\
\hline
\end{tabular}

On the other hand, verbs have only monosyllabic and disyllabic forms with the shape: $\operatorname{Prefix}(\operatorname{Pr})+\operatorname{Root}(\mathrm{Rt})+\mathrm{Final}$ $\operatorname{Vowel}(\mathrm{Fv})$ in the infinitive. Example (b)

\begin{tabular}{|c|c|c|}
\hline & \multicolumn{2}{|l|}{ E-gwá } \\
\hline & E-rísí & (English) \\
\hline & ó-fóyóju & "umbrella" (Efik, Nigeria) \\
\hline & $\varepsilon$-sanja & "loin" (Duala) \\
\hline ii) & $\varepsilon$-póm-é & "to pomp" (English) \\
\hline & 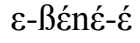 & "to bend" (English) \\
\hline
\end{tabular}

This simple word structure is also seen to occur in foreign lexical items (nouns and verbs)

However, it is important to also note that not all foreign lexical items adopt the above shape during lexical expansion. There are some nouns that get into the recipient language while maintaining the shape as in the source language. That is they have zero prefix as exemplified in (d):
d) $\quad \phi$-zín
$\emptyset$-míta
$\emptyset$-mísínja
"zinc"
"meter"
"messenger"

The above discussion gives a leeway for the presentation of the mechanism of lexical expansion by looking at how the core element is being manipulated to express the desired concept of foreign lexical items in to Ejagham language.

\section{3) Mechanisms of Lexical Extension}

\section{1) Borrowing}

The most spontaneous method for expanding the vocabulary of the Ejagham language is through borrowing. This involves the outright adoption of foreign lexical items from other languages the target language is in contact with. According to Chumbow (1982), speakers may be pushed by either prestige or needfeeling motive to borrow from another language. The prestige motivation is manifested in situations where a language borrows lexical items not because it lacks equivalents, but because the donor language enjoys a higher social status than the recipient language.

\begin{tabular}{|c|c|c|c|}
\hline 1)Indigenous word & borrowed word gl & loss & donor language \\
\hline$\varepsilon$-kin & lédyô & "radio" & English \\
\hline y-gwit ndzúp & tósìn & "thousand" (frs) & English \\
\hline akú-éyan & kəràsín & "kerosene" & English \\
\hline$\varepsilon-\sin$ & mótò & "motor car" & English \\
\hline$\varepsilon-\beta a ́ y \varepsilon ́$ & básíkò & bicycle/motor bike" & English \\
\hline
\end{tabular}
The result of such prestige-motivated borrowing is often the co-existence of two words, one foreign and the other native, for the same concept in the recipient language. For example

\footnotetext{
${ }^{2}$ Morphemic mixing refers to the use of morphemes from two languages within the same lexical item. Khati Thekiso (1985, 
The needfeeling motive on the other hand comes into play when the receptor language actually lacks lexical items for a particular concept and there is the conviction that a borrowed word and not an indigenously created one stand greater chances of expressing the idea or concept in question. Words such as those in (2) below now make up part of the Ejagham lexicon thanks to the needfeeling motive.

$\begin{array}{ll}\text { 2)Ejagham } & \text { borrowed word } \\ \text { zîn } & \text { "zinc" } \\ \text { lámîs } & \text { "lime" } \\ \text { ntâm } & \text { "times" (frequency) } \\ \text { fəláwa } & \text { "flower" } \\ \text { súka } & \text { "suger" }\end{array}$

Motivated by either of the two motives, Ejagham native speakers have a choice to make between internal (local) and external sources from which to borrow. The borrowed items/concepts undergo various processes (morphological/phonological/morphophonological/morphosyntactic) to suit the structure of the recipient language. Borrowing is obtained through the following means in Ejagham;

\section{1a) Loan words:}

The recipient language borrows the form as well as the meaning associated with the form to fill the gap or to designate new objects and practices. The use of this expresses a new concept better than the one that can be coined out of the internal linguistic resources. The following examples in (3) illustrate this type of borrowing.

3) Keràsín

Pípà

trósa

súkà

tósìn

jnôs

píà

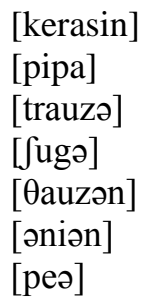

kerosene
paper
trousers
sugar
thousand
onion

A close look at the above examples indicates that there is a kind of modification in the loan items. The donor language is a stress-timed language whereas the recipient is a tone language. Consequently, in an attempt to naturalise the borrowing, the stressed syllable in the donor language adopts a high tone in the recipient and the unstressed syllable automatically adopts the low tone. As indicated earlier, the Ejagham language does not have diphthongs. As such, Loan words with such sounds have their syllables modified either by shortening the vowel or by inserting a consonant to break the vowel cluster. When this occurs a tone is inserted in the segment.

\section{1b)Loan adaptation}

This is another form of borrowing in which the structure of the borrowed words are subjected to phonological and morphological restructuring designed to make them conform to the phonetic and syllabic structures of the receiving language. Ejagham has specific morphological and grammatical properties crucial to its viability which are absent in the donor language. Consequently the loans into the receptor language have to provide these properties. One of the ways this is done in Ejagham is through Prothesis ${ }^{3}$. The examples in (4a) and (4b) illustrate:

4) a.

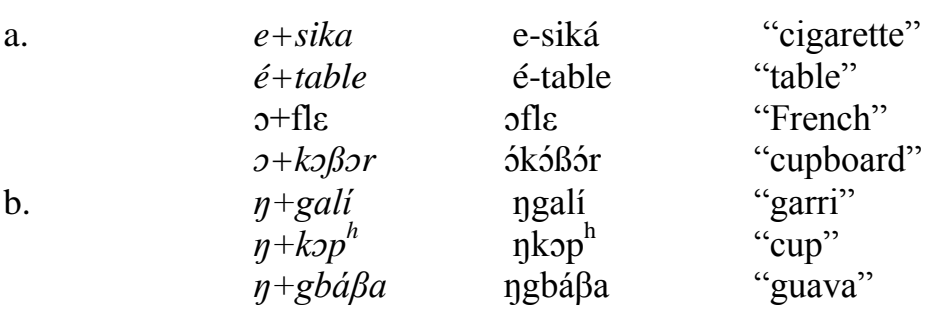

As shown in these examples, the vowels e-, o- in (a) and the nasal $\mathrm{N}$ - in (b) are prefixed to the borrowed word in the left column to fit the noun class system. Thus in Ejagham borrowed words have to be inserted into an appropriate class and assign the class markers (singular/plural) as exemplified in (c) below where some nouns neatly pattern in gender c)Gender $1 / 2$

$$
\begin{aligned}
& \text { n-kô } \beta \text { bo-kô } \beta \text { " cup (s)" } \\
& \text { غ́-tćbel bé-tźbel "tables (s)" } \\
& \text { ó-kóßór a-kóßór "cupboard (s)" }
\end{aligned}
$$

\footnotetext{
${ }^{3}$ Prothesis involves the introduction of new sounds at word-initial position. Mutaka and Tamanji (1995) 104
} 
It may be imperative to note also that the prefix + root structure does not hold true for all loan items in the singular. A few loan items have $\varnothing$ - (zero morpheme) in the singular gender while morpheme for class 2 (plural) is bo as can be exemplified in Ejagham where borrowed nouns neatly pattern in gender as in 5 below

Examples 5

Gender $1 \mathrm{a} / 2$

$\begin{array}{lll}\text { - }- \text {-rédyò } & \text { bò - rédyò } & \text { "radio(s)" } \\ \text { - } \varnothing \text {-dókin } & \text { bò-dókin } & \text { "padlock(s)" } \\ \text { - } \text {-windô } & \text { bò-windô } & \text { "window(s)" } \\ \text { - } \varnothing \text {-bókêr } & \text { bò-bókêr } & \text { "bucket(s)" }\end{array}$

Phonologically, borrowed words are subjected to one or even all of the following re-structuring processes in order for them to be in consonance with the inherent system of the target language.

Another adaptation process is through re-interpretation of strange segments where some sound segments attested in the donor language are absent in the receptor language. These "strange" sounds will be approximated to the indigenous sound segments with which they have the highest degree of phonetic similarity. Thus in Ejagham, the sounds $/ \int$, $t \int$, $\partial, \Lambda$, ai/ become s, o, d, i/a respectively as illustrated in (6)

$\begin{array}{cll}{\left[\int\right] \text { initial in "shilling" becomes }} & \text { sćrên } \\ {[\mathrm{t} f] \text { (final) in "church" becomes }} & \text { tfós } \\ {[ð] \text { as in "father" becomes }} & \text { fadá } \\ {[\Lambda] \text { as in "summon" becomes }} & \text { sómós } \\ {[\text { ai] as in }} & \text { "rice" becomes } & \text { c-rísi } \\ \text { as in } & \text { "lime" becomes lámîs }\end{array}$

\section{1c) Loan Shift:}

Loan shift involves either borrowing a concept and adapting material in the receiving language to express the concept or extending a partial equivalent in the receiving language to cover all aspects of the model in the donor language. Example: (6a) illustrates the first case while (6b) illustrates the latter:

6a English (Donor)

Heaven (From Latin: Cielum)

Angel

Holy spirit
Ejagham (Receptor)

ósó (literarily meaning "up")

Éßár éfún óßasi (white image of God)

$\varepsilon$-fún oßasi (picture of God)

English borrowed the concept of the Supreme Being and his "kingdom" from Latin". The Ejagham speakers have in turn adapted Ejagham words from English to express these concepts.

6b) English (Donor)

Ejagham (Receptor)

Wine

Whisky

$\mathrm{a}-\mathrm{mem}$

Beer

Soft drinks (juice)

Ejagham native speakers use the word "a-mem" to refer to the various types of drinks expressed by different lexical items in English.

3.1d) Cluster simplification: Vowels may be inserted to break abnormal consonant clusters coming from the donor language. For instance, in Ejagham borrowed words having consonant clusters ( e.g br, kr, gr, fl, etc) are immediately modified to eliminate such clusters which are strange to the language. For Example:

$\begin{array}{ll}\text { 7) ókolo } & \text { "okra" } \\ \text { غ́-táfél } & \text { "tafle" (Dutch- arm board) } \\ \text { geráma } & \text { "grammer" } \\ \text { berér } & \text { "bread" }\end{array}$

Despite the fact that there are consonant clusters in the language (Bakume 2019, Watters 1981), not all combination of clusters are acceptable. The preferred syllable structure of Ejagham is CV-. Strange syllables with CCV structure are broken up by the epenthesis of another vowel to give CVCV structure as can be seen above. When this occurs there is also a kind of prosody harmonization which can be explained by the fact that most African languages are tone languages. That is, they make use of relative contrastive pitch to distinguish words.

\footnotetext{
${ }^{4}$ English borrowed the concepts "God", "heaven" from Latin Deu(s), Cielu(m) respectively but adapted English phonemes to express the concept. (cf. French Dieu/ciel and Italian Deo/Cielo) Chumbow, (1982a).
} 
On the other hand, most Indo-European languages in contact with African languages are stress-timed languages where stress (or loudness) has a cumulative function in signaling prominence. Chumbow and Tamanji (1994). Loan words into Ejagham must therefore be made to bear tone and function under the same tone rules as indigenous words of the language.

The lesson from the spontaneous mechanism of language development is that the receptor African language - in this case Eajagham tends to match stressed syllables (i.e. syllables carrying primary stress) in the donor language with high tones and the unstressed syllables with low tone as evidenced in (8) below

8) Ejagham
'fótò
' $\varepsilon$-rísì
gerámà

$$
\begin{aligned}
& \text { English } \\
& \text { "photo" } \\
& \text { "rice" } \\
& \text { "grammar" }
\end{aligned}
$$

Although Ejagham has three contrastive pitch levels: High (H), Mid (M) and Low (L) Curiously, quite often, in a planned or conscious lexical innovation, there is a tendency for native speakers to simplify the tonal patterns of loan words (by eliminating mid tones) thus giving new words the simplest tone melodies consistent with the acceptable tone patterns and tone rules in Ejagham. This partly accounts for the reason why borrowing is the most common means of lexical expansion in this language. Chumbow and Tamanji (1994) explain this occurrence in stronger terms saying:

Lexical extension by borrowing constitutes the most productive process of lexical innovation. It is, however, stigmatized by Africanist of a purist persuation who instead preconise the use of the phonological, morphological, and morphosyntactic resources of the indigenous languages to coin new terms in response to the challenge of expressing new knowledge in science and technology in African languages.

\subsection{Internal resource mechanism (Coinage)}

Apart from borrowing, other productive processes of lexical innovation involve the creation of new words by exploiting resources (phonological, morphological and morphosyntactic) internal to the language. Coinage is a means of exploiting internal resources. Thus a new word is introduced into the language but expressed by the laguage's own resources. In Ejagham such productive processes include: composition, calque, derivation, reduplication, onomatopoea, compounding, tones and neologism.

\subsection{1) Composition}

This involves putting two items together to shape the concept. New indigenous words or expressions denoting foreign objects or concepts hitherto unknown to Ejagham native speakers are often easily created by combining some of its morphemes, words, or even phrases. By so doing, the aim is either to characterize the foreign objects and concepts or to simply replicate their meanings. Accordingly, composition actually subsumes two distinct strategies, notably; translation and description. In the examples (9), the left column shows each lexical item in Ejagham. Below it is the translation in English, while the right column indicates the concept expressed by a combination of the items.

9)a- items

$$
\text { njû }+ \text { oßasì }
$$

(house) (God)

$$
\text { Ésúkùr + àjî }
$$

(orange) (witches)

mbày + òkáré

(nut) (whiteman)

ákép + àyíp

(bones) (water)

$\begin{array}{ll}\text { njúòßàsì } & \begin{array}{l}\text { concept } \\ \text { "church" }\end{array} \\ \text { Ésúkùrájì } & \text { "lemon fruit" } \\ \text { mbàyókáré } & \text { "coconut" } \\ \text { áképáyíp } & \text { "ice" }\end{array}$

It could be noticed from the above examples that a noun combines with either another noun or with an adjective to shape the concept. In yet another situation, a particular lexical item; say a noun combines with other words to yield new concepts which originally did not exist in the language. For example in Ejagham the word $n j \hat{u}$ "house" combines with other words to yield the following:

b- item
njû + ngwìt
(house) (book)
njû + oßàsì
(house) (God)
njû + ablân
(house) (medicines)

\author{
New concept \\ "school" \\ "church" \\ "hospital"
}


On the other hand, lexical expansion by description occurs in Ejagham when technical terms denoting objects and concepts hitherto foreign to a culture are created by referring to some attributes of the objects or concepts. The most commonly encountered of such attributes are: function or purpose, appearance, behaviour. Some of these attributes exploited in Ejagham to create new words include:

\section{0) a.Function/purpose}

\begin{tabular}{|c|c|c|}
\hline etí nsesú & "grinding stone" & (lit. stone for grinding pepper) \\
\hline 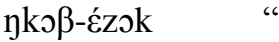 & "radio" & (box that produces noise) \\
\hline ćtí-ngwit & "pen/pencil" & (stick for school) \\
\hline $\begin{array}{l}\text { njû owit } \\
\text { b. Appearance }\end{array}$ & “library” & (house for books) \\
\hline mó jà & “insect" & (lit. small animal/creature) \\
\hline nìnó njúp “a & “aeroplane” & (lit. big bird) \\
\hline $\begin{array}{l}\text { nkak òkû/ nàyà nd } \\
\text { c. Behaviour }\end{array}$ & dép “soldier" & (lit. one who puts on uniform dresses/beats the buttock) \\
\hline$n t \varepsilon \beta \varepsilon t \int \hat{1}$ & "muslim” & (lit. one who hits the head on the ground) \\
\hline ̣kén àmîn "I & "Nigerian" & (lit. one who speaks with a lot of nasal sounds) \\
\hline d. Peculiar Chara & acteristics & \\
\hline nkûyàtâ "t & "troussers" & (dress for the lapse) \\
\hline Efĩ ókáré & television" & (whiteman's mirror) \\
\hline
\end{tabular}

\subsubsection{Calque}

This involves an imitation of how the original concept is shaped in the contact language. In Ejagham language, new words and phrases from another language are formed by semantic translation of its parts either by word-for-word or morpheme-by-morpheme as exemplified in (11)

\begin{tabular}{|c|c|c|}
\hline 11) Emànź + દ́jò̀ & Émànćjò & "sleeping sickness" \\
\hline $\begin{array}{l}\text { tá }+ \text { mìy }+ \text { á }+ \text { ygún } \\
(\text { prfx })(\text { light })(\text { ass. marker })+(\text { fire })\end{array}$ & támìyângún & "fire fly" \\
\hline $\begin{array}{l}\text { Emàné + atú } \\
\text { (sickness) (night) }\end{array}$ & Emàyátú & "night fever" \\
\hline$\varepsilon \mathbf{k} \mathbf{k}$ + ó́ + màmá & Ekəyว́ màmá & "an old mother" \\
\hline
\end{tabular}

(old) (ass. Marker) (mother)

The above examples show that a concept can be derived from several components at a time. Interestingly, in a word such as "fire fly" above, the verb mìn combines with the associative marker $\boldsymbol{a}$ to derive a noun mìn $\hat{a}$ which signifies "lighter" or "that which lights".

\subsection{3) Derivation}

In the Ejagham language, derivation differs from composition (i.e. description and translation) in that, whereas the latter makes use of distinct lexical items, the former involves the use of affixes attached to lexical morphemes belonging to a particular grammatical category. This often results in a change of the original grammatical category. Thus, affixation can cause nouns to be derived from verbs and adjectives, and adjectives from nouns and verbs. The following examples in (12a) and (12b) illustrate these derivations
(12) a. y-gy-ctûm
n-sén- $-\dot{\varepsilon}$
n-tónó
$\varepsilon-k \dot{y}$ ó
ntúb-ótú $\beta \varepsilon ́$
"worker"
(lit. one who works: from yin śtûm "to work")
"secretary/writer" (lit. one who writes: from sćy "to write")
"teacher"
"grater"
(lit. one who teaches: from the word tóý "to teach")
b. o-là
"hunter"
(lit. that which grates: from the word kj́k "to grate")
"height/length" (lit. that which is tall/long: from the word là-là "long")
o-nwán
"wiseness"
"beauty"

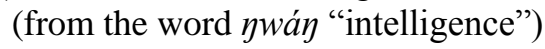
(that which is nice: from nù "nice"

\subsection{4) Reduplication}

Reduplication is used to express regular or customary activities, intensity of adverbs, laying of emphasis, superlative degree of adjectives, etc. The following examples from Ejagham (13) illustrate reduplication
13) tí - tí
"very much"
(much much)
là - là
"very long" 


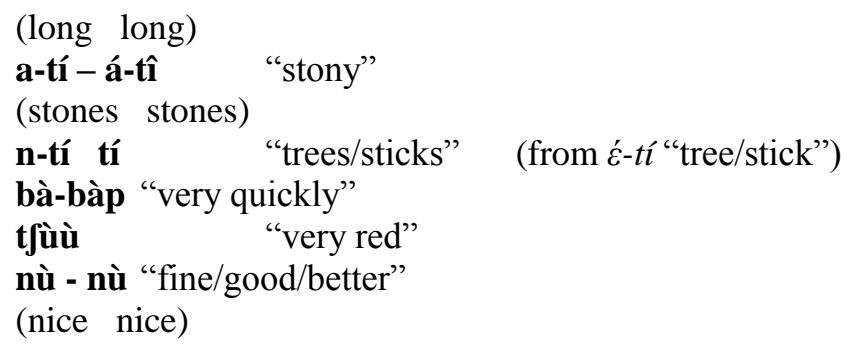

As shown in these examples, the roots of nouns and adjectives can be repeated or doubled to lay emphasis, for plurality or to express intensity of a quality. With respect to the last example, the idea expressed by each adjective is determined by the context.

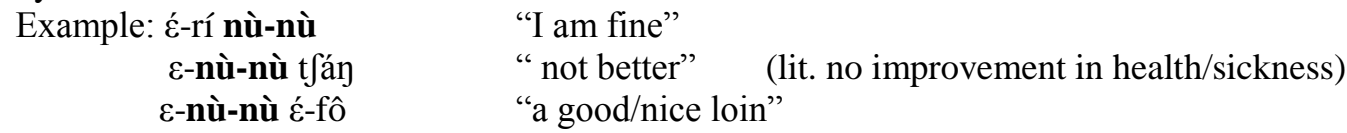

\subsection{5) Tones}

Tones play a significant role in expanding the lexicon in the Ejagham language. A change in tone on a lexical item brings about change in meaning as shown in the following examples:

$\begin{array}{ll}\text { 14) ńsí } & \text { "father" } \\ \text { nsì } & \text { "ground/earth" } \\ \text { nsí } & \text { "fish" } \\ \text { ykû } & \text { "dress" } \\ \text { ykù } & \text { "vomit } \\ \text { jkú } & \text { "rat mole" }\end{array}$

\subsection{6) Onomatopoea}

It is interesting to note that some lexical items get their names from the sound they produce. Most especially instruments in Ejagham derive their names in this way. This helps to increase the lexical stock of the language. Some instruments named after the sounds they produce include:

15)

$$
\begin{array}{ll}
\text { ykélánká } & \text { "bell” } \\
\text { ykán-ykán } & \text { "gong" } \\
\text { azák } & \text { "clappers" (made out of Indian bamboos) } \\
\text { ywan-ywan } & \text { "lightening" }
\end{array}
$$

\section{Conclusion}

Conclusively, it can be observed that words get in to the Ejagham lexicon through varied means. Borrowing and coinage of all forms, be it in spontaneous or in conscious language development is of utmost importance because words which are adapted to the phonological and morphological structure of the Eajagham language have a high acceptability factor and tend to be adopted and used rapidly. Whereas words that do not conform to the morpheme structure constraints of the Ejagham language but maintain the "foreignness" of the donor language are difficult to learn and therefore tend to be rejected spontaneously. Therefore terminology specialists introducing new concepts by borrowing into the language have to "nativise" the foreign word to facilitate its adoption and acquisition by Ejagham speakers. The adaptation processes to be used depend on the lexical, morphological and morpho-syntactic characteristics of the Ejagham language vis-à-vis similar properties of the donor language as demonstrated in both borrowed and coined items. In terms of lexical categories, nouns are generally more amenable to borrowing than verbs and adjectives which tend to favour coinage. Borrowed words are prevalent in various scientific and technical disciplines presumably because they make it easy for scientific and technical knowledge to be brought into the receptor language.

\section{References}

Bakume, N.M. (2002). The phonology of Loanwords in Ejagham. Maitrise Dissertation. University of Yaounde 1 Breton, R. and B. Fohtung (1991). Atlas Administratif des Langues National du Cameroun ALCAM, CERDOTOLA, CREA, ISH MESIRES, Yaounde

Chumbow, B.S. (1982). Language standardisation and language engineering in Chumbow, B.S. (Ed.), Applied Linguistics in Africa: an introduction. Lagos: Pumark Nigeria Ltd. 
Chumbow, B.S. and Tamanji, P. (1994). Development of terminology in African languages: Mechanisms of lexical expansion. M.S. University of Yaounde 1

Grimes, B.F. (2000) (Ed.) Ethnologue: languages of the world. (14 ${ }^{\text {th }}$ ed.) Vol. 1. Dallas Texas: SIL International.

Mutaka, M. N. and P.N. Tamanji (1995). An introduction to African linguistics. Ms. Universite Catholique d'Afrique Centrale ICY and University of Yaounde 1

UNESCO (2007). Mother Tongue-based Literacy Programmes: case studies of good practice in Asia, Bankok: Bankok, UNESCO Press.

Watters, J.R. (1981). A Phonology and Morphology of Ejagham with notes on dialect variation. Ph.D. Dissertation, University of California, Los Angeles. 